\title{
ECOLOGICAL STUDY ON ZOOPLANKTON OF SOME FRESH WATER BODIES OF KATHMANDU VALLEY WITH REFERENCE TO WATER QUALITY
}

\author{
S. R. Vaidya and U. K R. Yadav
}

\begin{abstract}
The present investigation was carried out in Bagmati river (Lotic water body), Taudah lake, Nag pokhari pond, Siddha pokhari pond and Godavari fish pond (Lentic water bodies) of the Kathmandu valley from May 2000 to April 2002. A monthly samples of water and zooplanktons were collected from those sites and analyzed for the entire twenty four months period. Only three groups of zooplankton viz: Rotifera, Cladocera and Copepoda were collected from the lotic and lentic water bodies. It was observed that Rotifers were found to be more diversified than Cladocerans and Copepods in all water bodies except in Nagpokhari. A total of seventy one species of zooplankton were recorded during that period. The lentic water bodies supported a higher species richness constituting seventy species whereas the lotic water bodies constituted only seven species of zooplankton. All investigated zooplanktons Rotifera, Cladodera and Copepoda were found contagiously distributed in all lentic water bodies. In the Bagmati river, Rotifers were recorded only in the upstream zone. Cladocerans predominated $(74 \mathrm{z} \%)$ in the upstream, Copepods predominated $(70 \%)$ in the mid-stream and again Cladocerans predominated $(60 \%)$ in the down-stream of the river. Among the investigated water bodies, the species richness was found higher in Godavari fish pond (36 species) than Taudah lake (35 species), Siddha pokhari (34 species) and Nag pokhari (26 species). The water quality of the investigated waterbodies were found to be deteriorated due to discharge of untreated effluents,solid wastes and poor conservation practices.
\end{abstract}

Key words: Cladocera, copepoda, diversity index, rotifera, zooplankton

\section{Introduction}

For the existence and continuity of life, water is one of the essential component of the earth. Water occupies about 362 million kilometers (71 \%) of the total area of the earth's surface. As compared to marine and terrestrial habitats, fresh water habitats occupy a relatively small portion of the earth's surface but their importance to man is far greater than their area (Odum, 1996).

According to Hynes (1978) the quality of aquatic environment has inevitably been largely associated with the problems caused by the discharge of certain effluents arising from human industry or the excreta of man and his livestock. The freshwater environment supports the high biological diversity. Zooplanktons play a vital role in the community nutrition of the fresh water system and hence assume importance in aquaculture activities. Fresh water zooplankton is dominated by four major groups of invertebrates, Ciliated protozoans, Rotifers and two subclasses of the Crustacea ; the Cladocera and Copepoda. 
Certain species of zooplankton are good indicators of water quality and hence referred to as biological indicators. Arora 1961 has received the use of planktonic organisms as pollution indicators. Species diversity index $(\mathrm{H})$ is a measure of the number of species present in a community and influenced by physical and chemical qualities of water. Hence it could be used towards the assessment of water quality (Kurup, 1990).

The rapid population growth and poor land use are creating major problems related to the freshwater environment (Miller 1994).

The purpose of this study is to analyse physico- chemical parameters of the Bagmati river, Taudha lake, Nag pokhari, Siddha pokhari and Godavari fish pond of Kathmandu Valley and to make Qualitative and Quantitative study of zooplankton collected from these water bodies.

\section{Description of Study Area}

The present investigation has been carried out on the physico-chemical parameters and zooplankton of the Bagmati river, three fresh water ponds located at different districts of Kathmandu valley namely the Siddha Pokhari (Bhaktapur district), Nag Pokhari (Kathmandu district), Godavari Fish Pond (Lalitpur district) and one natural fresh water Lake Taudah of the Kathmandu valley. The Bagmati river is the largest river of Kathmandu city originating from the sourthern slope of Shivapuri ridge, Baghdwar, north of Kathmandu at an elevation of 2650 m.above the sea level flowing intravenously through Kathmandu city covering a length exceeding $30 \mathrm{Km}$. ( Sharma, 1977 ) and leaving Kathmandu city from Chovar gorge drains into the Terai region and finally mixes into the river Ganga of India.Its main tributary is Bishnumati, other tributaries are Prabhawati, Bhadramati, Rudramati, Manamati, Hanumati, Ikshumati and Nakhukhola.During the present investigation period water and zooplankton samples were collected from three sampling stations; Up-stream zone at Gokarna, Midstream zone at Thapathali and Down-stream zone at Chovar.

Nag pokhari is an artificial rain feed pond surrounded by dense households,located in the eastern part of the Royal palace ward no.1 of Kathmandu Meteropolitan city. Eutrophication is the main problem of this pond due to poor conservation practices.

Siddha pokhari pond is one of the famous pond of the Bhaktapur district located in ward no.17 Inatole of Bhaktapur submetropolitan city.The pond previously known as Indra Daha as the God of Rain Indra bathed in this pond.The pond has permanent inflow and out flow but it is mostly fed by rain water. According to the local residence, there are seven wells present within the pond that fed the pond all around the year, hence the pond maintains the water level even during dry season.

Godavari fish pond is situated at the highest elevation in the foothill of the Pulchowki (Valley's highest mountain) about $12 \mathrm{Km}$. southeast to Kathmandu city, $5100 \mathrm{ft}$. above the sea level. This farm has the oldest history as a mother institution among all the fishery stations spread all over the kingdom. The water supply in the farm comes through a small creeks that generates from the northern end of Pulchowki hills.

Taudha, a famous natural lake located about $6 \mathrm{Km}$. southwest from the Kathmandu city of 
ward no.11 of Kirtipur Municipality.The peculiarity of the lake is that if viewed from any of its corner, one can not see all the corners of the lake. The lake has permanent inflow and outflow covering an area of 4 hector.Eutrophication due to human encroachment, siltation and also succession by vegetation.Fig.1.

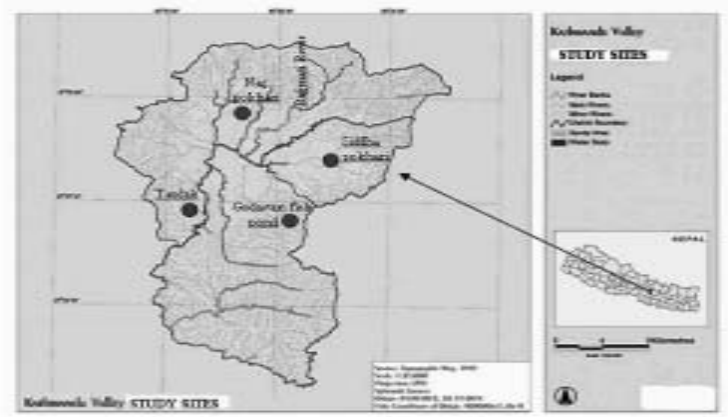

(Map source: ICIMOD, 1999)

Figure1: Location map of study sites in the Kathmandu valley

\section{Material and Methods}

Physico-chemical parameters of water

Temperature, Secchi Disc Transparency, water velocity, $\mathrm{pH}$, dissolved oxygen, free carbon dioxide, alkalinity, hardness and Calcium content of water were measured in the field. For the determination of Conductivity, nitrate and phosphate collected water samples were brought in the laboratory of Viswa Niketan Science Campus, Balaju. Publications of APHA (1989) and Trivedy and Goel (1986) were followed for the analysis of physico - chemical parameters of the collected water samples.

\section{Zooplankton Sampling and analysis}

The zooplankton was collected by using a plankton hand net. Two hundred and fifty litres of water was filtered through the plankton net with the mesh size of $60 \mathrm{~m}$. In order to collect zooplankton like rotifer species adhering to the weeds, the weeds were taken into bucket and rinsed vigorously and the water from the bucket was sieved through the blotting nylon cloth. The filtered sample was suspended in $50 \mathrm{ml}$ of water and brought to the laboratory. The plankton were immediately fixed and preserved in $5 \%$ formalin to avoid deterioration of the materials.

The quantitative analysis of the zooplankton was done by using sedgewick rafter cell (Welch, 1948). The preserved plankton samples were filtered and made up into $2 \mathrm{ml}$ of water. The total number of zooplankton in one cubic meter of water (m3) was calculated and the values expressed as number of animals per cubic meter of water (No.m3). For the qualitative analysis of zooplankton, formalin preserved sample were observed under compound microscope of magnification $10 \times 15$. The identification of the zooplanktonic organisms were done to generic level using the standard books of Hutchinson (1957), Edmondson (1959), 
Needham and Needham (1962) and Pennack (1989). Shannnon Species Diversity Index $(\mathrm{H})$, Evenness index (e), Index of Dominance (c) and index of similarity (S) were determined following Odum, 1996.

\section{Statistical analysis}

The correlation between abundance of zooplanktons and physicochemical parameters and their significance was analyzed by using SPSS 11.5 software.

\section{Result and Discussion}

Altogether seventy one species of zooplankton were recorded from both the lotic and lentic water bodies during the present investigation period,Table 1. Out of the seventy one species of zooplankton recorded, only seven species of zooplankton were found in the Bagmati river. Three species of zooplanktons Leucane (L) ungulate, Acroperus sp. and Daphnia lumholtzi were recorded only in up-stream zone, one species, Neodiaptomus handelli only in midstream zone and Kurzia longirostris only in down-stream zone of the Bagmati river. Only one species, Cyclops viccinus was found in all three zones and Moina micrura in both midstream and down-stream zones of the Bagmati river. Present study indicates more or less similar values of zooplankton diversity in all three investigated zones (0.4503 in up-stream, 0.4539 in mid-stream and 0.4581 in down-stream) of the Bagmati river. Rotifers were recorded only in the up-stream zone and not from mid-stream and down-stream zones of the Bagmati river. Cladocerans predominated in the up-stream and formed about $74 \%$ of the total zooplankton collected from the up-stream zone of the Bagmati river. Copepods predominated in the mid-stream zone and formed about $70 \%$ of the total zooplankton collected from the mid-stream zone. Cladocerans were also found dominated in the down-stream zone and formed about $60 \%$ of the total zooplanktons of the down-stream zone of the Bagmati river.

Winner (1975) and Steveninck et al. (1992) have pointed out that water velocity plays an important role in the both composition and abundance of zooplankton in the lotic water ecosystems. Comparatively the slower moving parts of the river water supports.

Table 1: General frequency and abundance of Zooplankton recorded in the Siddha pokhari, Nagpokhari, Godavari fish pond, Taudah lake and Bagmati river in the Twenty four monthly samples during the investigation period 2000 May to April 2002.

\begin{tabular}{|l|l|c|c|c|c|c|c|c|}
\hline $\begin{array}{l}\text { S. } \\
\text { N. }\end{array}$ & $\begin{array}{c}\text { Zooplankton } \\
\text { Pokhari }\end{array}$ & $\begin{array}{c}\text { Nag } \\
\text { Pokhari }\end{array}$ & $\begin{array}{c}\text { Godavari } \\
\text { Fish Pond }\end{array}$ & $\begin{array}{c}\text { Taudah } \\
\text { lake }\end{array}$ & Up str & Mid Str & Down Str \\
\hline 1 & Asplanchan brightwelli & I & - & - & Tho & - & - & - \\
\hline 2 & Asplanchnopus sp. & IA & - & Two & - & - & - & - \\
\hline 3 & Brachionus bidentata & Fio & - & A & - & - & - & - \\
\hline 4 & B. calyciflorus amphiceros & Fro & - & Tho & I & - & - & - \\
\hline 5 & B. calyciflorus V. dorcas & Tho & So & - & - & - & - & - \\
\hline
\end{tabular}




\begin{tabular}{|c|c|c|c|c|c|c|c|c|}
\hline 6 & B. calyciflorus f.annuraeiformis & Tho & 1 & Two & - & - & - & - \\
\hline 7 & B.calyciflorus & - & - & Tho & - & - & - & - \\
\hline 8 & B.caudatus v.acculeatus & IA & - & - & - & - & - & - \\
\hline 9 & B.caudatus f. masculusju & Two & - & 1 & - & - & - & - \\
\hline 10 & B.caudatus $f$. vulgatus & Two & - & - & - & - & - & - \\
\hline 11 & B.falcatus v. lyratus & So & - & - & IA & - & - & - \\
\hline 12 & B.forficula f. minora & Fro & - & - & - & - & - & - \\
\hline 13 & B.Patulus & - & Two & - & IA & - & - & - \\
\hline 14 & B.quadridentatus v. clunorbicularis & Fro & - & - & - & - & - & - \\
\hline 15 & B.quadridentatus meltheni & - & - & So & - & - & - & - \\
\hline 16 & B.quadridentatus f. rhenanus & 1 & 1 & Fio & - & - & - & - \\
\hline 17 & B.quadridentatus & - & - & - & 1 & - & - & - \\
\hline 18 & B.rubens & Fio & Fro & Fro & IA & - & - & - \\
\hline 19 & B.urceolaris & Tho & - & - & - & - & - & - \\
\hline 20 & Euchlanis dilatata & - & - & - & So & - & - & - \\
\hline 21 & Keratella lenzi & Fro & - & - & - & - & - & - \\
\hline 22 & Keratella tropica & So & Tho & 1 & So & - & - & - \\
\hline 23 & Keratella valga & - & 1 & 1 & - & - & - & - \\
\hline 24 & Lepadell sp. & - & - & - & Fio & - & - & - \\
\hline 25 & Platyias leolopi & So & - & - & So & - & - & - \\
\hline 26 & P.trgonnellus & - & - & - & Fro & - & - & - \\
\hline 27 & Lecane $(L)$ curvicornis & So & - & So & - & - & - & - \\
\hline 28 & L. (L) luna & - & - & - & So & - & - & - \\
\hline 29 & L. (L) ungulate & - & - & - & So & Tho & - & - \\
\hline 30 & Lecane sp. & - & - & Two & - & - & - & - \\
\hline 31 & Cephadella sp & - & - & So & So & - & - & - \\
\hline 32 & Embata cornmensalis & - & - & - & So & - & - & - \\
\hline 33 & Filinia longiseta & - & A & So & - & - & - & - \\
\hline 34 & F. terminalis & - & - & - & So & - & - & - \\
\hline 35 & Pompholyx sulcata & So & - & - & - & - & - & - \\
\hline 36 & Trichocera sp. & - & - & So & - & - & - & - \\
\hline
\end{tabular}




\begin{tabular}{|c|c|c|c|c|c|c|c|c|}
\hline 37 & Bosmina longirostris & - & - & Tho & - & - & - & - \\
\hline 38 & Acroperus harpae & So & - & - & - & - & - & - \\
\hline 39 & Acroperus sp. & - & - & - & - & Two & - & - \\
\hline 40 & Alona pulchella & Two & - & Tho & - & - & - & - \\
\hline 41 & A. rectangular & So & - & Fro & So & - & - & - \\
\hline 42 & Chydorus parvus & - & Fro & - & So & - & - & - \\
\hline 43 & Chydorus ventricocus & - & - & - & So & - & - & - \\
\hline 44 & Chydorus sp. & - & - & Tho & A & - & - & - \\
\hline 45 & Kurzia longirostris & - & - & - & Two & - & - & Fro \\
\hline 46 & Pleuroxus laevis & - & - & A & A & - & - & - \\
\hline 47 & P. trigonellus & - & - & - & Tho & - & - & - \\
\hline 48 & Pseudochydorus sp. & - & - & - & 1 & - & - & - \\
\hline 49 & Ceriodaphnia cornuta & - & - & A & - & - & - & - \\
\hline 50 & C. laticoenis & Two & So & - & Fro & - & - & - \\
\hline 51 & Ceriodaphnia sp. & - & Fro & - & - & - & - & - \\
\hline 52 & Daphnia carinata & So & A & A & A & - & - & - \\
\hline 53 & Daphnia lumholtzi & So & Tho & $\mathrm{A}$ & - & Tho & - & - \\
\hline 54 & Daphnia pulex & - & So & Fro & - & - & - & - \\
\hline 55 & Moinadaphnia macleyi & - & Two & - & - & - & - & - \\
\hline 56 & Moina micrura & Tho & $\mathrm{I}$ & So & - & - & Tho & Two \\
\hline 57 & Simocephalus laticornis & - & Tho & - & - & - & - & - \\
\hline 58 & S. ventulus & Fro & - & Fro & IA & - & - & - \\
\hline 59 & Scapholeberis kingisars & Fro & Fio & IA & A & - & - & - \\
\hline 60 & Macrothrix goeldii & - & - & Tho & - & - & - & - \\
\hline 61 & M. laticornis & - & Fio & Fio & So & - & - & - \\
\hline 62 & M. spinosus & - & - & Fro & 1 & - & - & - \\
\hline 63 & Diaphanosoma sarsi & - & - & So & - & - & - & - \\
\hline 64 & Cyclops vicinus & IA & RA & RA & RA & Two & Tho & Fro \\
\hline 65 & Mesocyclops hyalinus & - & IA & A & I & - & - & - \\
\hline 66 & M. leuckarti & 1 & - & - & $\mathrm{I}$ & - & - & - \\
\hline 67 & Diaptomus sp. & - & Fro & - & - & - & - & - \\
\hline
\end{tabular}




\begin{tabular}{|l|l|c|c|c|c|c|c|c|}
\hline 68 & Heliodiaptomus viduus & Two & Fio & Tho & So & - & - & - \\
\hline 69 & Neodiaptomus handelli & Fro & Two & - & - & - & So & - \\
\hline 70 & N. schamackari & - & Tho & - & - & - & - & - \\
\hline 71 & Nauplii larvae & RA & A & RA & RA & - & - & - \\
\hline
\end{tabular}

RA - Regular and abundant

I - Irregular

IA - Irregular but abundant

Fro - Recorded on four occasions
Fio - Recorded on five occasions

Tho - Recorded on three occasions

Two -Recorded on two occasions

So -Recorded on single occasion

higher number of zooplankton than faster moving parts. The water velocity in up-stream zone may be considered as one of the important factors for low species diversity and abundance of zooplankton. The other factors such as short retention of nutrients, washing out of eggs and food availability (Dizk and Zanten 1995) also contribute for the occurrence and abundance of zooplankton.

Particularly at mid-stream and down-stream zone showed an erratic fluctuation in $\mathrm{pH}$ values throughout the study period. It may be due to the fact that both sites receive different types of untreated effluents as the river enters the urban region. Low dissolved oxygen content of water at both mid-stream and down-stream zones of the Bagmati river may be due to the discharge of untreated wastewater that increased organic load and decomposition of which by bacteria and fungi may decrease the dissolved oxygen content. Similarly, the lower total hardness, nitrate content and orthophosphate content of the water of upstream and their higher concentration in mid-stream and downstream may also due to addition of untreated effluents into the river as the river reached to the urban region.

An average value of species diversity of zooplankton was found more or less similar in upstream (0.4503), mid-stream (0.4539) and down-stream (0.4581) zones of the Bagmati river during the present investigation period as shown in Table 2. 
Table 2: Average values of species diversity and eveness index in three zones of Bagmati river, Taudah lake, Nag pokhari, Siddha pokhari and Godavari fish pond over twenty four months period ( May 2000 - April 2002)

\begin{tabular}{lcc}
\hline & species diversity $(\mathrm{H})$ & Eveness $(\mathrm{e})$ \\
\hline up-stream zone of Bagmati river & 0.4503 & 0.7478 \\
Mid-stream zone Bagmati river & 0.4539 & 0.9513 \\
Down-stream zone Bagmati river & 0.4581 & 0.9602 \\
Taudah lake & 0.6541 & 0.7770 \\
Nag pokhari & 0.4886 & 0.6146 \\
Siddha pokhari & 0.5583 & 0.7487 \\
Godavari fish pond & 0.6264 & 0.744 \\
\hline
\end{tabular}

The present study indicates that all three zones of the Bagmati river support low species diversity of zooplankton. Comparatively the value of eveness index was found low in the upstream zone (0.7478) than in mid-stream (0.9513) and down-stream (0.9602) zones of the Bagmati river. Lentic water bodies support much higher species diversity of zooplankton than the Bagmati river in the Kathmandu valley. Altogether seventy species of zooplankton were recorded from the lentic water bodies during the present investigation period. Of the three groups of zooplankton, rotifers were found comparatively highly diversified (36 species), than Cladocerans (26 species) and Copepods (8 species) in the lentic environment. Among the investigated water bodies, the number of zooplankton species was found slightly more in Godavari fish pond (36 species) than Taudah lake (35 species) and Siddha pokhari (34 species). The number of zooplankton species was found lowest (26 Species) in Nag pokhari. Rotifers were found comparatively more diversified in Siddha pokhari (20 species) than in Taudah lake (16 species) Godavari fish pond (16 species) and Nag pokhari (8 species). Cladocerans were more diversified in Godavari fish pond (16 species) than Taudah lake (14 species), Nag pokhari (11 species) and Siddha pokhari (9 species). Copepods were more diversified in Nag pokhari (7 species) than in Taudah lake (5 species), Siddha pokhari (5 species) and Godavari fish pond (4 species).

The number of zooplanktons showed an erratic fluctuation in all the investigated lentic water bodies throughout the investigation period. However the high numbers were usually recorded from Janaury to May. Similar high peak of abundance of zooplankton was obtained in spring season by Dijik and Zanten (1995). Khatri (1992) also obtained a high abundance of zooplankton dominated by Copepods and Rotifers during the same season.

It was found that there was inverse relationship between ecological dominance and species diversity of zooplankton in all the investigated sites. It may be so because high value of Shannon Weiner diversity index a low concentration of dominance (Odum, 1996). The highest community similarity index of 0.80 was found for the Copepoda community between Taudah lake and Siddha Pokhari which indicates that both of these water bodies have similar 
environmental factors favourable for the Copepoda.

A negative correlation was found between abundance of zooplankton and dissolved oxygen values of water in Taudah lake (- 0.2553), Nag Pokhari (- 0.2629) and Godavari fish pond (- 0.3964) and a positive correlation in Siddha Pokhari (0.0653). All of these are not significant at 0.05 significance level (two-tailed). It shows that there is no significance correlation between abundance of zooplankton and dissolved oxygen of water. However, a positive correlation between abundance of zooplankton and dissolved oxygen was obtained by Mahato (1988), Mandal (1992) and Yadav (1996) but the test of significance is not done for those values.

In general it may be said that in Taudah Lake the abundance of zooplankton showed a significant positive correlation with none of the observed physico-chemical parameters of water whereas a significant negative correlation was observed only between the abundance of zooplankton with temperature and orthophosphate content of the water. In Nag pokhari the abundance of zooplankton showed a significant positive correlation with none of the measured physico-chemical parameters of the water whereas a significant negative correlation was found between the abundance of zooplankton with temperature and $\mathrm{pH}$. In Godavari fish pond, the abundance of zooplankton showed a significant positive correlation only with free carbon dioxide content whereas a significant negative correlation was observed between the abundance of zooplankton with temperature and $\mathrm{pH}$. In Siddha Pokhari, the abundance of zooplankton showed a significant positive correlation only with orthophosphate content of water whereas a significant negative correlation was obtained with neither of the observed physico-chemical parameters of water.

\section{Conclusion}

During the present investigation in Bagmati river, Taudah lake, Nag Pokhari pond, Siddha Pokhari pond and Godavari fish pond from May 2000 to April 2002, a total of seventy one species of zooplankton were recorded. The lentic water bodies supported a higher species richness constituting seventy species whereas the lotic water bodies constituted only seven species of zooplanktons. The species diversity of zooplankton was also found to be lower in the lotic water bodies which was more or less equal in upstream, mid-stream and downstream portion of the river. Among different lentic water bodies, the highest average ecological dominance was observed in Nag Pokhari. In the Bagmati river, Rotifers were recorded only in the upstream zone. Among the investigated water bodies, the species richness was found higher in Godavari fish pond (36 species) than Taudah lake (35 species), Siddha Pokhari (34 species) and Nag Pokhari (26 species). All investigated zooplanktons Rotifera, Cladodera and Copepoda were found contagiously distributed in all lentic water bodies. The water quality of the Bagmati river was found to be deteriorated from upstream to downstream probably due to the discharge of untreated effluents into the river. Mostly, the concentration of chemicals in the water were found to be lower in rainy seasons. A significant positive correlation was observed between the abundance of zooplankton and orthophosphate content in Siddha Pokhari and also in between the abundance of zooplankton and free carbondioxide content in Godavari fish pond whereas the a significant negative correlation was observed in between the abundance of zooplankton and temperature in Taudah lake, Godavari fish pond and Nag Pokhari; in between the abundance of zooplankton and $\mathrm{pH}$ in Godavari fish pond 
and Nag Pokhari and also in between the abundance of zooplankton and orthophosphate in Taudah lake.

In general, habitats with congenial environmental condition will have more number of species each represented by small populations whereas habitats affected by several environmental factors will show reduced number of species (Thienemann's first law : Dajoz, 1977). The species diversity index of zooplankton of the investigated water bodies has been measured first time in the present investigation.

\section{Acknowledgements}

We would like to express our deepest gratefulness to Prof. Dr. Ravindra Kumar Sinha, Head of the Environmental Biology Laboratory, Department of zoology, Patna University, Patna for providing us necessary facilities required for the studies.

\section{References}

American public Health Association. 1985. Standard methods for the examination of water and Waste water 16th ed, APHA, New York:1268

Arora, H.C. (1961). Rotifers as indicators of pollution - CPHERI Bull, 3(4):24.

Brehm, V. (1953). Indische Diaptomiden, Pseudodiaptomiden und Cladoceren Ost. Zoology 4:241-345.

Dijik, G.M.V. and Zanten, B.V. 1995. Seasonal changes in zooplankton abundance in the lower Rhine river during 1987-1991. Hydrobiologia, 304:29-38.

Dumont, H. J. and Van de Velde, (1977). Report on a collection of Cladocera and Copepoda from Nepal. Hydrobiologia, 53(1):55-65.

Hamilton, F. (1819). An account of the Kingdom of Nepal. Pp 65. Reprinted by Manjusri Publishing House, New-Delhi in 1971.

Hutchinson, G.E., (1957). A treatise on Limnology Vol. I. John Willey and sons. London:1015.

Hynes, H.B.N, (1978). The biology of polluted waters. Sixth immersion. Liverpool University press, 123 Grove street, Liverpool L7 7AF:1-4.

Khatri, T.C. (1992). Seasonal distribution of zooplankton in Lakhotia lake. Environment and Ecology, 10(2):317-322.

Kirkpatrick (1811). An account of the Kingdom of Nepal. Reprint 1975, Asian Publication Services, New Delhi.

Kurup, G.U. (1990). Species Diversity in Environmental Management and conservation. Taxonomy in Envi. Biol.303 - 315.

Loffler, H. (1969). High altitude lakes in Mt. Everest region. Vern, Internal Verein Limnol,17:373385.

Mahato, D.D. (1988). Study on some physico-chemical parameters of a temple tank (Kirtipur) in relation to zooplankton production. A dissertation submitted to Central Department of Zoology , Tribhuvan University:49-55 
Mahato, N. (1994). Study on abundance and percentage distribution of zooplanktons in sewage disposal pond (Secondary) Dhobighat, Lalitpur, Nepal. A dissertation submitted to Central Department of Zoology, Tribhuvan University, Kathmandu.

Mandal. B.K. (1992). Limnological studies in relation to zooplankton productivity of "Bhi pukhu Pond" Kirtipur. A dissertation submitted to Central Department of Zoology , Tribhuvan University. Miller, G.T.Jr.(1994). Living in the environment Wadsworth Pub. Comp. California.

Needham, J and Needham, P.R., 1962. Guide to the study of fresh water Biology. Holden-day Inc. Sanfrancisco:106

Odum, E.P., (1996). Fundamental of Ecology. W.B. Sanders Company, philodelphia and London:574

Pennak, R.W.,(1991). Freshwater Invertebrates of the United States: Protozoa to Mollusca, Third edition, A Wiley Interscience Publication, John Wiley \& Sons, INC., New York, Chichester, Brisbane, Toronto, Singapore:1-126.

Regan, C.T. (1907). Reports on a collection of fishes from Nepal and the Western Himalayas. Rec. Ind. Mus, 1:157-158.

Sharma, C.K. (1977). River Systems of Nepal. Navana Printing Works p1, 47 Ganesh Chunder Avenue, Calcutta.

Shrestha, S. (1999). Comparative study on the effect of some physico-chemical parameters on the production and seasonal distribution of zooplanktons in the pond no. 1 and pond no. 2 of Central Fish Hatchery, Balaju, Kathmandu.

Steveninck, E.D.de Ruyter van, W.A. Admiraal, L. Breebaart, G.M.J. Tubbing and B.van Zanten. (1992). Plankton in the River Rhine: structural and functional changes observed during down-stream transport. In: Jour. Of Plankton Research, 14(10):1351-1368.

Trivedi, R.K., and Goel, P.K., (1986). Studies on river pollution in Kathmandu Valley, Indian J. Environ, Health 24(2):124-135.

Welch,P.S., (1948). Limnological methods.

Winner, N. (1948). In: Cynbernetics, Wiley, New York:194.

Yadav, L.P. (1996). The effects of physco-chemical parameters on the distribution and abundance of zooplankton in Taudaha lake (a natural) lake. A dissertation submitted to Central Department of Zoology, Tribhuvan University

Yadav, U.K.R. (1996). Water quality and biotic community of oxbow lakes of the Chitwan National Park. Second International Seminar on Water and Environment, Nepal Chemical Society. April 7-9, 1-31.

\section{Author's Address}

${ }^{1}$ Mr. Sunil Ram Vaidya and ${ }^{2}$ Umakant Roy Yadav

${ }^{1}$ Department of Zoology, Patan Multiple Campus. Tribhuvan University.

${ }^{2}$ Department of Environmental Science, Kirtipur Multiple Campus.Tribhuvan University. 